\title{
5. MULTIBEAM BATHYMETRIC SURVEY OF THE LEG 78A DRILLING AREA AND COMPARISON WITH THE SOUTHERN PART OF THE BARBADOS RIDGE DEFORMATION FRONT ${ }^{1}$
}

\author{
Pascale Fontas, Institut de Géologie du Bassin d'Aquitaine \\ Pierre Valéry, Société Nationale Elf Aquitaine (P) \\ Patrick Le Quellec, Compagnie Française des Pétroles \\ Alain Mascle, Institut Français du Pétrole \\ Vincent Renard, Centre Océanologique de Bretagne \\ Marc Tardy, Université de Savoie \\ and \\ Bernard Biju-Duval, Institut Français du Pétrole ${ }^{2}$
}

\begin{abstract}
We have obtained an accurate bathymetric map of the lower slope and deformation front in the area of Leg 78A sites by means of a multibeam survey. We interpret N-S trends revealed by the survey to be asymmetric structural features linked to the westward subduction. The influence of the Tiburon Rise is not obvious in the drilling area, but clearly induces an E-W trend of structures immediately to the south of the rise. In the southern part of the Barbados Ridge the asymmetric folds are well expressed in the bathymetry as N-S elongate anticlines.
\end{abstract}

\section{INTRODUCTION}

The deformation front of the Barbados Ridge complex runs from south to north for several hundred kilometers (Fig. 1). As pointed out by Westbrook et al. (this volume), conventional geophysical techniques are not always adequate to get a good idea of the internal deformation in the accretionary prism. Moreover, the grid of seismic profiling generally does not allow a three-dimensional picture of the structure to be obtained in any case.

A very detailed geomorphological and structural study of the Barbados accretionary prism has therefore been conducted by the Comité d'Etudes Pétrolières Marines (CEPM) using multibeam and high-resolution seismic tools (CARVEN-Caraïbe-Venezuela-project). Recently Biju-Duval et al. (1982) have presented some preliminary results from the southern part of the Barbados Ridge complex, and have shown how the multi- narrowbeam sonar system (Sea Beam) has provided a third dimension to the cross-sectional structure visible on the seismic reflection profiles. As will be summarized here, the very detailed bathymetric survey has allowed us to obtain a good correlation between the present seafloor topography and the geological structures at the frontal part of the accretionary prism. In the Leg $78 \mathrm{~A}$ drilling

\footnotetext{
${ }^{1}$ Biju-Duval, B., Moore, J. C., et al., Init. Repts. DSDP, Vol. 78A: Washington (U.S. Govt, Printing Office).

2 Addresses: (Fontas) Institut de Géologie du Bassin D'Aquitaine, Laboratoire de Géologie et Océanographie, Avenue des Facultés, 33405 Talence Cedex, France; (Valéry) Société Nationale Elf Aquitaine (P), Tour Générale, La Défense 9, 5 place de la Pyramide, $92800 \mathrm{Pu}$ teaux, France; (Le Quellec) Compagnie Française de Pétroles, Tour Mirabeau, 39-43 Quai André Citroën, 75739 Paris, Cedex 15, France; (Mascle) Institut Français du Pétrole, B.P. 311, 92506 Rueil Malmaison, Cedex, France; (Renard) Centre Octanologique de Bretagne, 29272 Brest, Cedex, France; (Tardy) Universite de Frances (Biju- Coural, Freent France; (Biju-Duval, present address) Centre National pour l'Exploitation des Octans, 66 Avenue d'Iéna, 75116 Paris, France.
}

area, where seismic reflection profiling does not provide precise imagery of the internal deformation of the accretionary wedge (see Ngokwey et al., this volume), could this geomorphological approach give information about the tectonic style? That was the question when, before Leg 78A, the Centre National pour l'Exploitation des Océans (CNEXO) conducted a restricted bathymetric survey of the site area using the multibeam tool of the N/O Jean Charcot. The resultant limited coverage available at the time of the drilling has since been enhanced by a new survey made in July 1981 by CEPM-CNEXO.

This chapter will present briefly the new data obtained around the drilling area, our interpretation of these data, and comparisons with conditions at the southern part of the ridge.

\section{Multibeam Tool}

The Sea Beam is a multibeam echo-sounder which represents a considerable technological advance in marine cartography (Renard and Allenou, 1979). The Sea Beam produces 16 narrow beams (each $223^{\circ}$ wide) which, after roll stabilization, are processed in real time by a minicomputer. Data are acquired from a swath of the seafloor over which the ship is sailing (Fig. 2); coverage is roughly two thirds of the water depth. Contour charts are traced in real time on a digital plotter (Fig. 3). Sound velocity used is $1500 \mathrm{~m} / \mathrm{s}$. The scale is chosen by the operator, and the along-track distance is obtained by integration of the ship's speed. All data from the 16 beams are stored on a magnetic tape for later processing. Playback of bathymetric data and navigation data allows production of a bathymetric chart in geographic coordinates.

The preliminary survey was carried out with a Transit satellite navigation system. During the CARVEN project, the new survey used a radio positioning system (ARGO), but, owing to the distance of the Leg $78 \mathrm{~A}$ drilling area from the land stations, the final map of the site was drawn in geographic coordinates using satellite navigation and, because of the reproducibility of the acquired data, by track-to-track correlation of the bathymetric contours. 


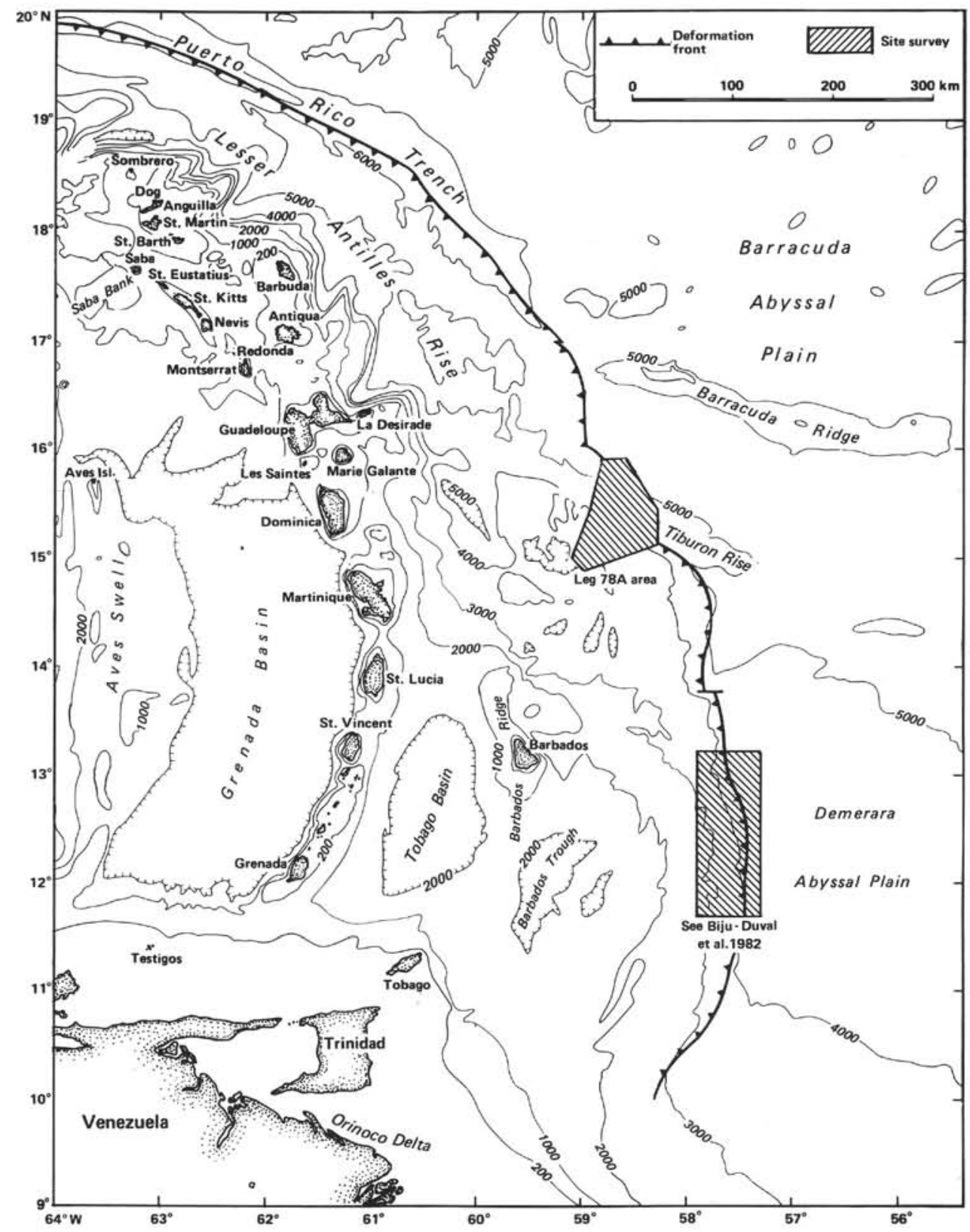

Figure 1. Location map of the bathymetric surveys. (Contour depths in $\mathrm{km}$.).

\section{MAIN PHYSIOGRAPHIC FEATURES}

Figure 4 gives the general Sea Beam bathymetric map around the drilling area (Tiburon survey). One can distinguish four distinct features:

1) The abyssal plain. This appears in the northeastern part of the survey, but unfortunately is not well covered: only an area of a few square kilometers shows a flat topography below a water depth of $4800 \mathrm{~m}$.

2) The Tiburon Rise. The topography of the rise regularly deepens toward the NW, with a gentle slope from 4200 to $4800 \mathrm{~m}$; we interpret rare slope breaks, oriented NNE or NE, to be fault scarps transverse to the rise. The northern part of the rise has not been mapped.

3) The deformation front. In the drilling area this is oriented N-S (Fig. 5). A narrow depression, 1 to $2 \mathrm{~km}$ wide, occurs between the Tiburon slope and the lower slope of the Barbados Ridge complex, oblique with respect to the Tiburon high. The northward slope of the elongate depression varies from 1 to $3.5 \%$. Westward the deformation front is well characterized by a gentle slope of 3 to $7 \%$ along N-S trend (Fig. 6, A-C).

To the south of the Tiburon Rise, the deformation front is oriented broadly W-E and butts against the rise with a steeper slope (Fig. 6, D and E, and Fig. 4).

The lower slope of the Barbados Ridge complex. North of $15^{\circ} 20^{\prime} \mathrm{N}$, the general slope is smooth and oriented broadly N-E, oblique to the deformation front (Fig. 5). In detail, the slope is relatively irregular and we can see (1) many irregularly distributed, discontinuous, and asymmetric N-S structures with steeper eastern flanks. Such structures are about 0.5 to $1.5 \mathrm{~km}$ wide, 1 to $4 \mathrm{~km}$ long, 


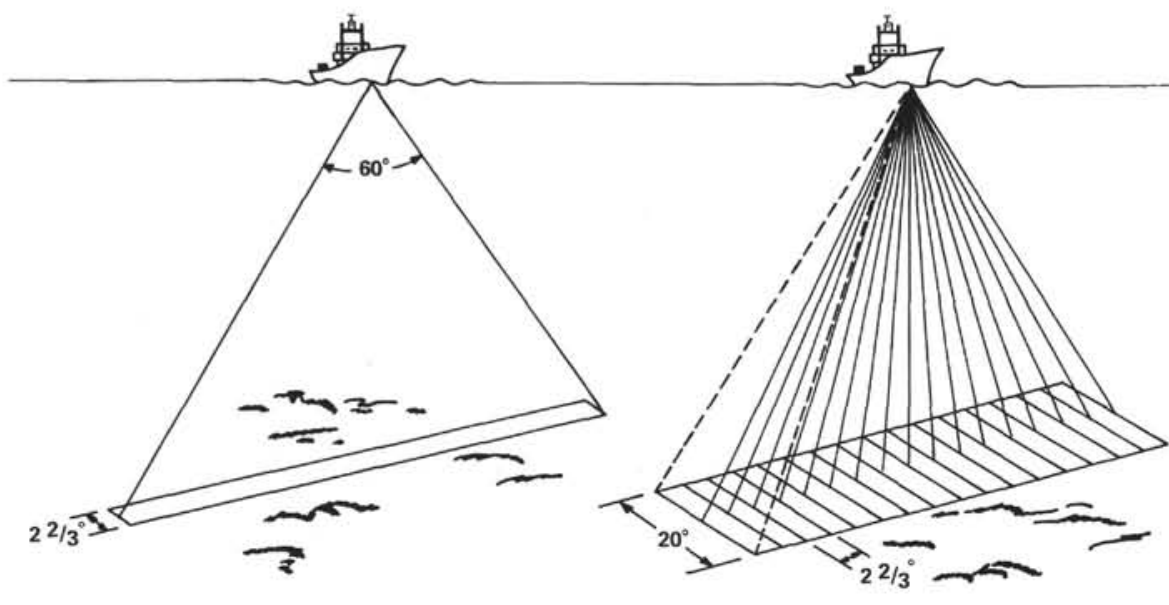

A

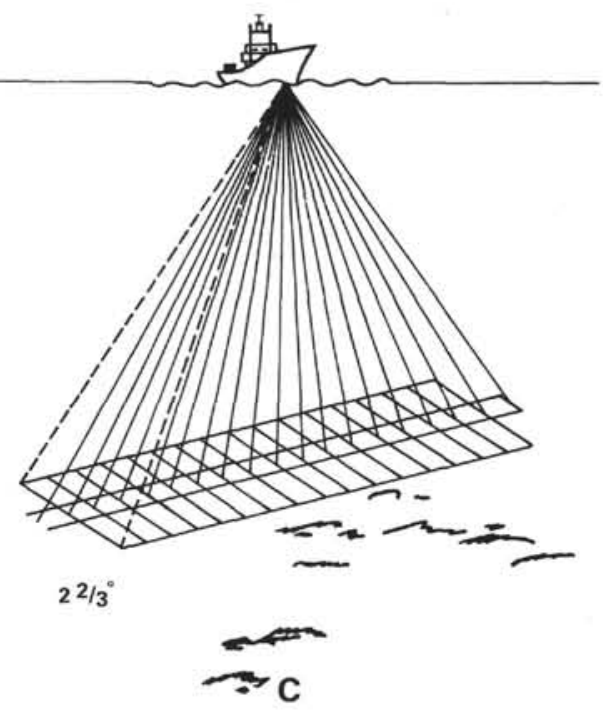

Figure 2. Diagram of the Sea Beam data acquisition system. (A) transmitter, (B) receiver, and (C) combination.

and generally only 25 to $50 \mathrm{~m}$ high; (2) some irregularly NNE-oriented transverse structures (e.g., Fig. 5).

South of the Tiburon Rise, in water up to $3200 \mathrm{~m}$ deep, stands a broad physiographic crest oriented E-W.

\section{MORPHOLOGICAL INTERPRETATION}

Our morphological interpretation is based on cartographic analysis of the natural land forms, and assumes that the seafloor relief reflects the underlying structure. First extended to the whole Tiburon survey (Fig. 4) and then restricted to the drilling area (Fig. 5), the analysis allows us to infer the style of tectonic deformation along the lower slope near the Tiburon Rise. In contrast with the case of the southern part of the Barbados Ridge complex, we can here evaluate the evolution of the deformation in the context of the anomalies and discontinuities of the downgoing plate.

\section{METHODS}

The seafloor relief may be represented on the one hand by conventional contour lines (bathymetric surface, Figs. 4 and 5) and on the other by a submarine valley network, the locus of the lower turning points of the surface (Fig. 7).

The principle of the study lies in the selection and measurement of morphological parameters whose variations are significant in reflecting the geological control. Several analytic parameters are treated in the present study: pattern and density of the network, abnormal lineaments in the valleys (valley-system analysis), and slope (surface analysis).

Network pattern. The network pattern may be broadly related to geological structure. The effect of structure upon the orientation and shape of networks is thought to occur in a direct manner as valleys develop along surface lines of weakness and may become at least partially adjusted to subsurface structures.

Abnormal lineaments in the valleys. These are deduced by comparing the arrangement of the valley system with the regional bathymetric surface. "Normal valleys" running conformably to regional lines of slope are removed. The residual network obtained ("abnormal lineaments"), cannot be linked to gravity control, and thus reflects structural trends or tectonic discontinuities.

Network density. The network density is believed to express the fineness of the structural or erosional texture of the landscape, giving characteristic patterns for homogeneous (weak valley frequencies) to fine-tex- tured topography (high density of tributaries). It may depend on sediment lithology.

Distribution of the slope values. The aim of the numerical analysis developed by Naudin and Prud'homme (1980) was to map and study the areal distribution of surface gradients. The analytic method they proposed can utilize a small computer system.

The treatment first depends on a reasonable sampling of spot heights for which rectangular coordinates are known. Concerning both the studied areas, a regular sampling has been achieved at intersection points of a $1-\mathrm{cm}^{2}$ grid drawn on the Sea Beam map at $1 / 100,000$. Then the average gradient of each triangular facet determinable within a unit-square area from three intersection points may be measured. The listed values are the values of the tangents of the slope angles measured along the steepest slope lines of the facets. From these values, given in percent, statistically significant isotangent values are plotted and the data are contoured.

The contoured representation permits one to interpret the overall landscape in terms of domains that have gentle, intermediate, and steep slopes. The slope pattern depicted on the surface may be related to underlying structural support, and studying it allows us to get accurate information about that underlying structure.

Distribution of slope anomalies. In order to investigate the distribution of slope anomalies it is necessary to define a regional slope surface. This may be thought of as a trend that represents a simple gradient of the distribution of slope values. Such gradients may be computed by the leastsquares method.

In the Naudin and Prud'homme (1980) problem, the studied surface is divided into subregions, each fit by a cubic order or lower polynomial. From this "mosaic," the regional surface is progressively constructed over the entire area in question and a residual map can be obtained. This is done by taking the differences at grid intersection points between the regional slope values and original slope values, each in values of percent. These differences may be plus, minus, or zero; that is to say, the true gradient value may be above the regional gradient, below it, or equal to it. Then statistically significant values of anomalies are plotted and the data are contoured to form the residual map.

Rather than their absolute values, however, the signs, trends, and locations of anomalies are taken into account for the final interpretation. Such a study brings new information about the distribution of residual forms locally unsuited to the regional structural pattern.

\section{TIBURON Survey: Analysis of Submarine Valley Network}

The submarine valley network (Fig. 7) is inferred from the general Sea Beam bathymetric map at the scale of $1: 100,000$. Major morphological domains are delineated primarily by obvious changes in the geometric charac- 


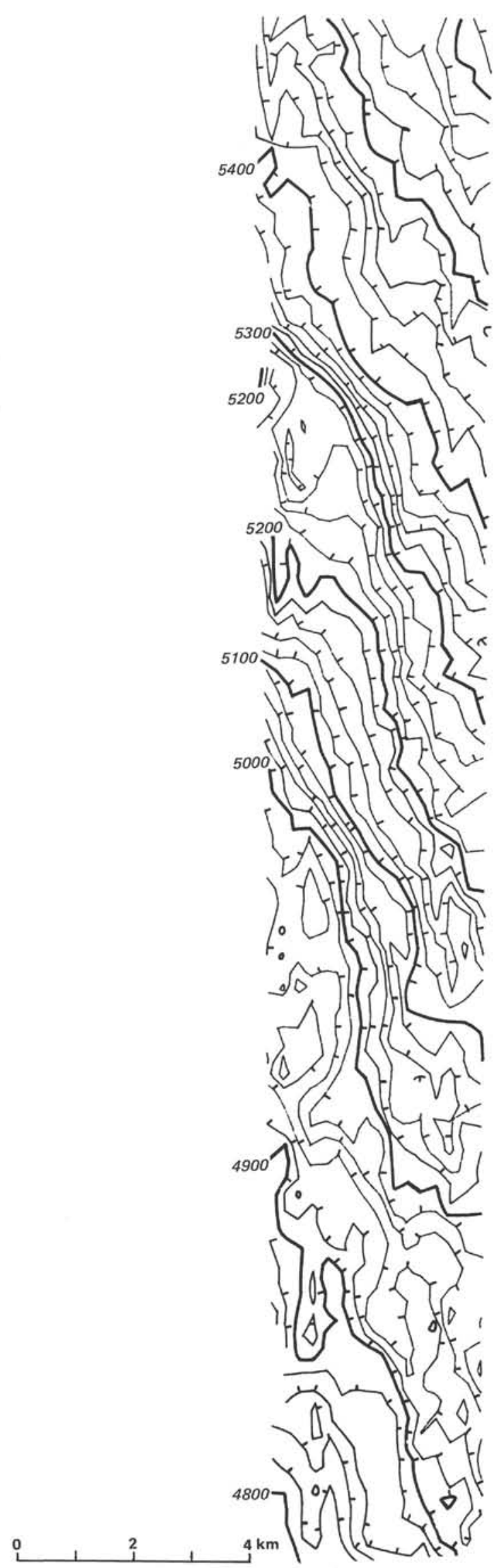

Figure 3. Example of plotter output. (Contour depths in m.). teristics of the network (shape, orientation, and density). This delineation is underlined by abnormal lineaments in the valleys, mapped in Figure 8 (see the regional surface given in Fig. 7).

Seaward, within the Tiburon Rise area (domain A), a network with a low density of valleys is depicted. The pattern follows the regional slope, except for NNE abnormal lineaments related to the interpreted fault scarps previously mentioned. The main $\mathrm{N}-\mathrm{S}$ valley marking out that seaward domain to the north is still visible south of $15^{\circ} 15^{\prime} \mathrm{N}$, where it runs $\mathrm{E}-\mathrm{W}$, but is largely obliterated east of $58^{\circ} 30^{\prime} \mathrm{W}$. Indeed, on the southeastern seaward area and above the deformation front, a complex radial network exists that is probably associated with the presence of a debris flow (see Belderson et al., this volume).

South of the Tiburon Rise, immediately within the deformation front (domain B), the valley-system geometry obviously has a pronounced structural control; the valleys bend at right angles and most of them are not aligned with the steep north-facing slope. Within the physiographic crest area farther south (domain C), there is a network with short tributaries developing on both sides of master valleys which trend E-W and WNW-ESE; such a basic pattern is generally formed on folded sedimentary rocks or on parallel fractures.

The abnormal lineaments in the valleys on both of these domains clearly define an E-W structural trend. In the western part of the area this trend appears to disrupt short NNW-SSE lineaments.

The complex zone including domains B and C seems to be under the direct tectonic influence of the nominally E-W Tiburon Rise. Effects of the rise are obvious as far as $30 \mathrm{~km}$ south of the deformation front. Eastwest trends can be interpreted as resulting from wrench faulting because of the important offset of the deformation front near $15^{\circ} \mathrm{N}$ (see Fig. 1).

To the north, domain B' (the drilling area) appears to be located beyond major influences noted before, and the deformation front is regularly oriented N-S.

The regional NE-facing slope does not control the whole structural pattern. Parallel N-S abnormal lineaments in the valleys emphasize the area. They define a fine-scale structural grain, locally interrupted along NW-SE and NE-SW cross-trends.

\section{The Drilling Area}

\section{Distribution of Slope Values}

The distribution of slope values (Fig. 9) is determined from a numerical surface analysis of the Sea Beam bathymetric map of the drilling area (Fig. 5). In that area there is clearly a very different distribution of slope values on either side of the deformation front.

Seaward, between the Tiburon Rise and the deformation front, the values do not exceed $7.8 \%$, and are more often represented by small slope values (2.4-3.8\%). Their distribution defines a N-S linear trend, especially in the smaller and intermediate slope values. This is slightly anomalous with regard to the regional NW-oriented slope. It is particularly obvious 6 to $8 \mathrm{~km}$ east of the front, and may indicate low-amplitude deformation in the abyssal 


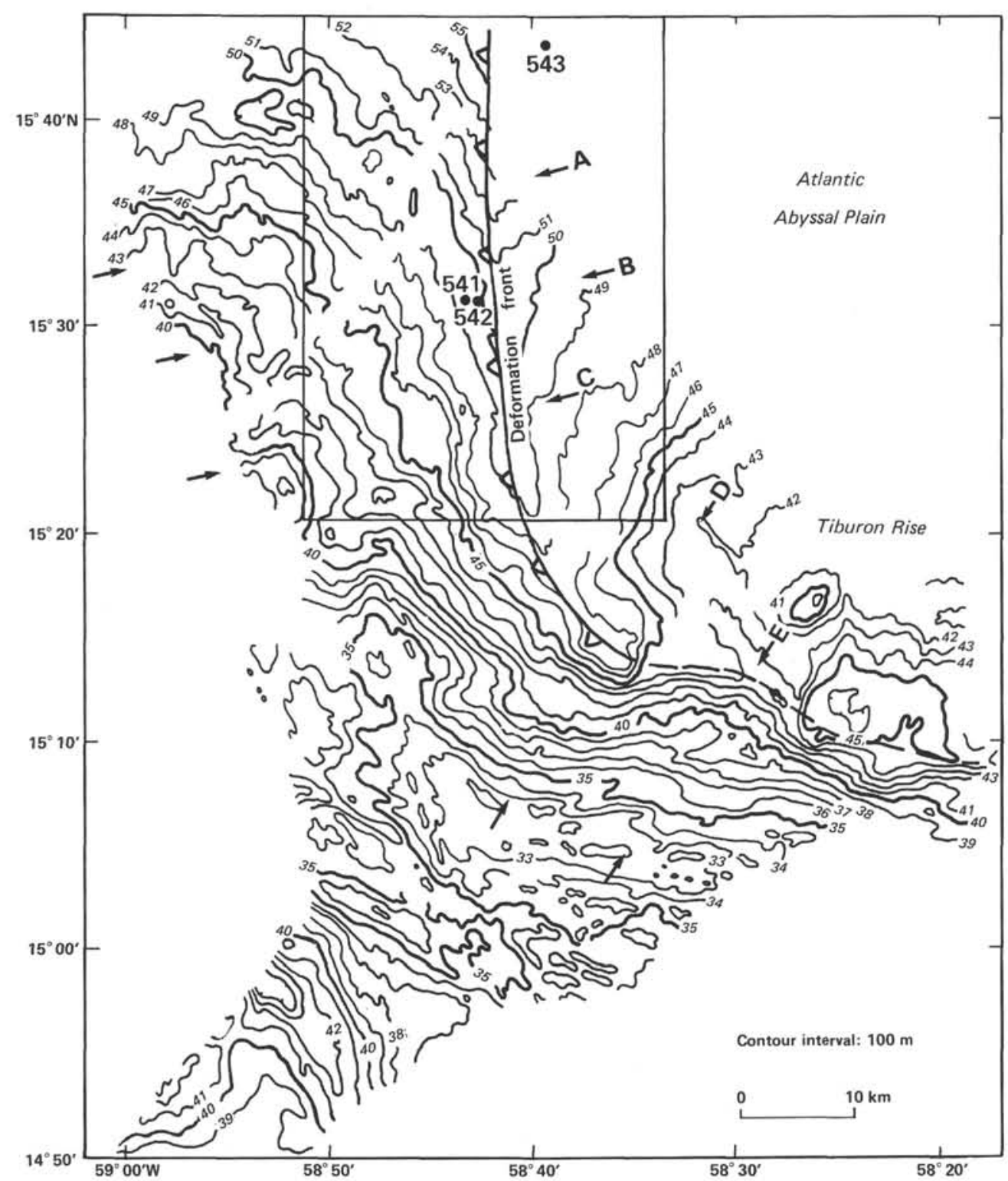

Figure 4. General Sea Beam bathymetric map around the drilling area (Tiburon survey). Arrows indicate locations of profiles A, B, C, D, and E on Figure 6. Inset is shown in detail in Figure 5.

sediments, such as has been seen in other localities on echo-sounder records (Stride et al., 1982). South of the shown E-W trend of slope break, cutting the Tiburon Rise near $15^{\circ} 20^{\prime} \mathrm{N}$, the frontal zone is deflected and the $\mathrm{N}-\mathrm{S}$ grain disappears. The southeasternmost part of the seaward domain shows smooth relief, with steeper slopes oriented NNE; these may indicate faults along the Tiburon Rise.

Landward, the lower slope of Barbados Ridge shows a N-S organization supported by steeper slopes (7.8$12 \%$ ) with eastward breaks. Such N-S features are discontinuous, broadly interrupted along NW-SE trends. Their length does not exceed $5 \mathrm{~km}$.

Thus, in a zone 10 or $12 \mathrm{~km}$ wide, major slope trends lie parallel to the deformation front. The essentially regular spacing of high-slope breaks $(1.5-2 \mathrm{~km})$ clearly defines a fine-scale structural grain. The lateral succession of sequences of gentle and steep N-S slopes may be re- lated, using geophysical data, to the asymmetric structures linked with the westward subduction. In such a scheme, each eastward high-slope break can be interpreted as the locus of outcropping of reverse faults induced by the E-W shortening. Because of the scarcity of good seismic reflection response in the discontinuously reflective sequence constituting the toe of the accretionary prism (see Ngokwey et al., this volume), this morphological analysis is therefore very useful.

Farther west, the sequential organization that was likely to indicate the identity of the folded structure tends to disappear.

\section{Anomalies of the Slope Values}

Anomalies of slopes (Fig. 10) are deduced from the distribution of slope values (Fig. 9) after removing the regional slope gradients. Such a treatment confirms the 


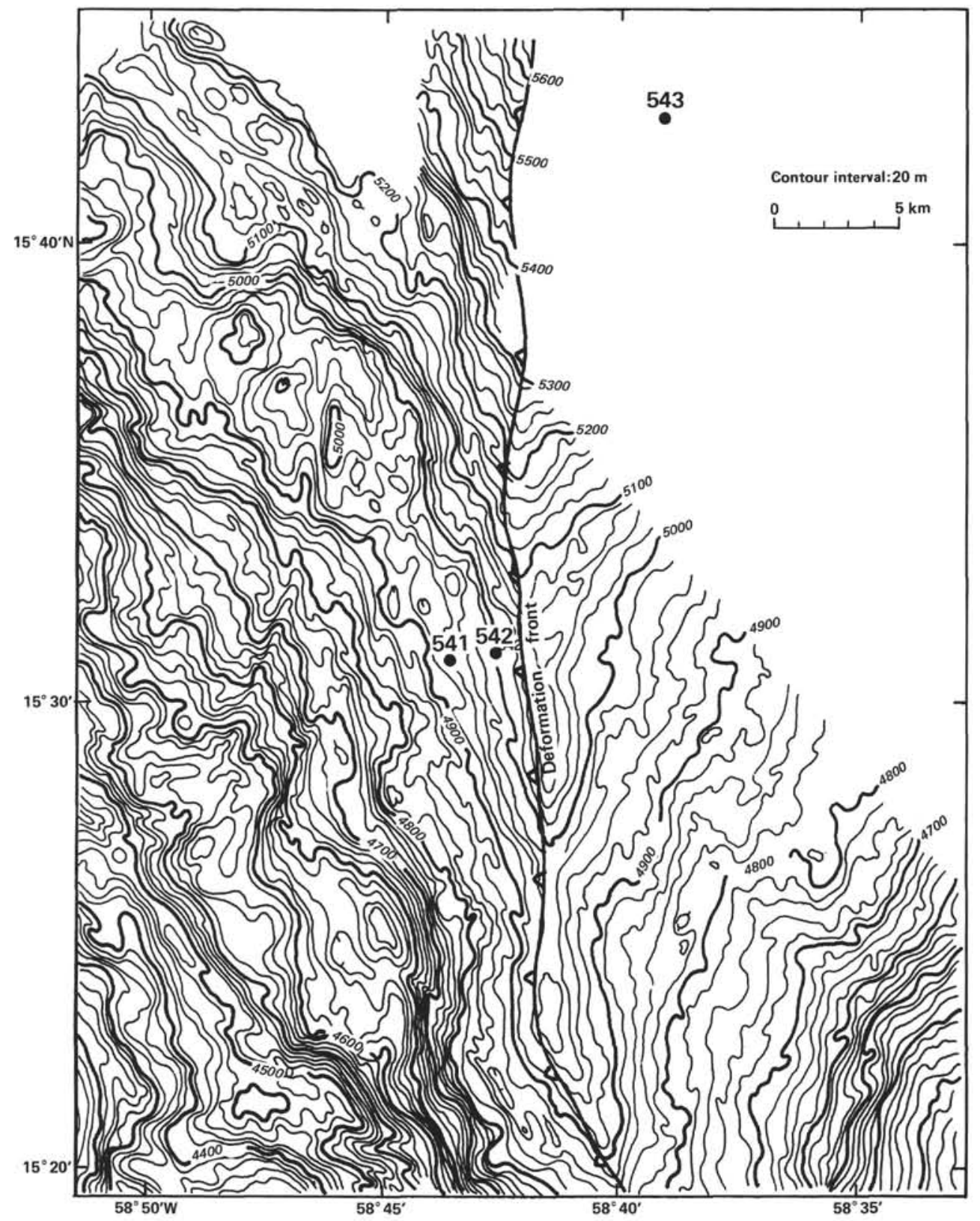

Figure 5. Sea Beam bathymetric map of the drilling area (inset in Fig. 4).

regional predominance of the N-S structural trend. Nevertheless, the spatial distribution of the positive and negative N-S elongate areas is obviously controlled by a NW-SE direction. Such a persistence of trend, extending across both the structures of the lower slope and the apparent offset of the deformation front at $15^{\circ} 30^{\prime} \mathrm{N}$, suggests that oblique faults cutting the $\mathrm{N}-\mathrm{S}$ frontal folding play a leading role in the deformation.

\section{COMPARISON WITH THE SOUTHERN PART OF THE BARBADOS RIDGE COMPLEX}

\section{Main Physiographic Features}

The southern survey, carried out between $11^{\circ} 45^{\prime} \mathrm{N}$ and $13^{\circ} 00^{\prime} \mathrm{N}$ (Fig. 1) provided the bathymetric map published by Biju-Duval et al. (1982), which shows a sharp transition between the Demerara Abyssal Plain and the lower continental slope (Fig. 11).

The deformation front south of $12^{\circ} 30^{\prime} \mathrm{N}$ is marked by N-S cuestas with about $300 \mathrm{~m}$ of elevation and with slopes ranging from 23 to $35 \%$ (Fig. 6).

Westward, two sets of N-S parallel and elongate hills occur 6 and $10 \mathrm{~km}$ from the deformation front; these are separated by narrow depressions. Seismic data clearly show that these morphological structures correspond to anticlinal folds coupled with eastward overthrusting (see Fig. 12 and Westbrook et al., this volume).

At $12^{\circ}, 12^{\circ} 10^{\prime}$, and $12^{\circ} 30^{\prime} \mathrm{N}$, the deformation front presents sinistral offsets of, respectively, 1.0, 0.7, and $2.5 \mathrm{~km}$. We interpret these as possible wrench faults oriented $\mathrm{N} 130^{\circ}$. They are still visible landward on the continuing scarps. 

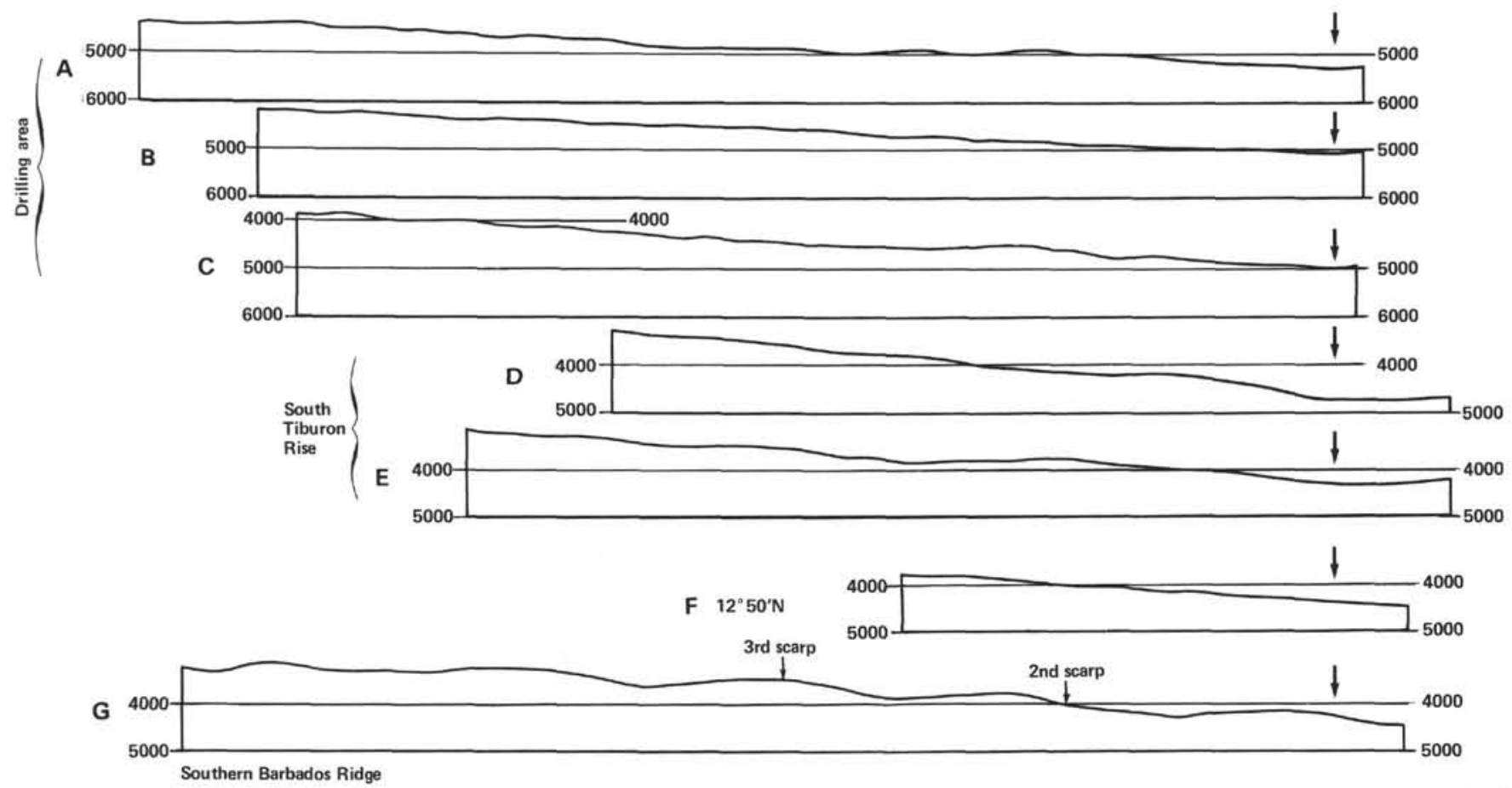

Figure 6. Topographic profiles across the deformation front. (Depths in m.) Comparison between the drilling area (profiles A, B, C), south of Tiburon Rise (profiles D and E), and southern part of Barbados Ridge (profiles F and G). The arrows indicate the deformation front; see locations on Figures 4 and 11.

Behind the third cuesta, the morphology is not so well organized. North-south hills $3 \mathrm{~km}$ wide and 10 to $20 \mathrm{~km}$ long are interpreted as asymmetric anticlines. This morphology of discontinuous antiforms and synforms progressively loses its character between 3600 and $3000 \mathrm{~m}$ of water depth. Shallower features become difficult to interpret.

Landward, this area of recent deformation progressively passes into the central Barbados Ridge, where one can observe depressions several kilometers-wide separated by small crests and ridges from which geophysical records show syntectonic infilling of synclines and complicated reverse high-angle folds (see Biju-Duval et al., 1982 and Westbrook et al., this volume). Both the bathymetric survey and high-resolution seismic profiling (Mascle et al., in press), seem to indicate mud volcanoes on the upper slope of the central Barbados Ridge complex and in the Barbados Trough. Argilokinesis, in which numerous extrusions create circular hills on the seafloor (Fig. 13), is thus important. The age of the source beds of the extruded clays is unknown. Similar mud diapirism southward in the Trinidad area has its source lower Neogene uncompacted clays (Higgins and Saunders, 1974). Mud extrusions are unknown in the drilling area.

The westward shift of the deformation front north of $12^{\circ} 30^{\prime} \mathrm{N}$ corresponds to a major change of the seafloor morphology. Here, as in the drilling area described above, the general slope is marked by discontinuous and weak $\mathrm{N}-\mathrm{S}$ anomalies. The slope is relatively steep (Fig. 6F) but without the synform morphologies that occur to the south (Fig. 6G).

\section{Geomorphological Interpretation: Distribution of the Slope Values}

The distribution of slopes south of $12^{\circ} 30^{\prime} \mathrm{N}$ (Fig. 14) is directly linked to bathymetric features. It emphasizes the lateral succession of antiforms and synforms and their westward evolution. The seaward cuestas are indicated by $\mathrm{N}-\mathrm{S}$ lineaments with high slope values averaging $25 \%$. They are bounded westward by a wider zone of gentle slopes, and are locally interrupted or flexed along discontinuities oriented $\mathrm{N} 130^{\circ}$. Landward, the N-S breaks of slope (14-20\%) are shorter and more discontinuous, interrupted by numerous small cross-features.

These slope values correspond quite well to the seismic imagery showing large asymmetric folds with eastfacing reverse faults at the deformation front and more irregular folding landward.

The mapping of the slope values north of $12^{\circ} 30^{\prime} \mathrm{N}$ clearly shows the presence of N-S breaks of slope, somewhat obliterating the obvious change noticed in the bathymetry between the northern and southern domains. The average of high slope values is less (14-17\%), but except for a shorter spacing the lateral arrangement of successive sequences of low and high slope trends is not so different from the southern one. The discontinuous fine-scale N-S trend of probable asymmetrical folds is largely disrupted along the trend of steep cross-slopes oriented NW-SE.

Such an organization, with relatively short N-S structural features shifted along oblique trends, is similar to that in the drilling area. Using available seismic data, one 


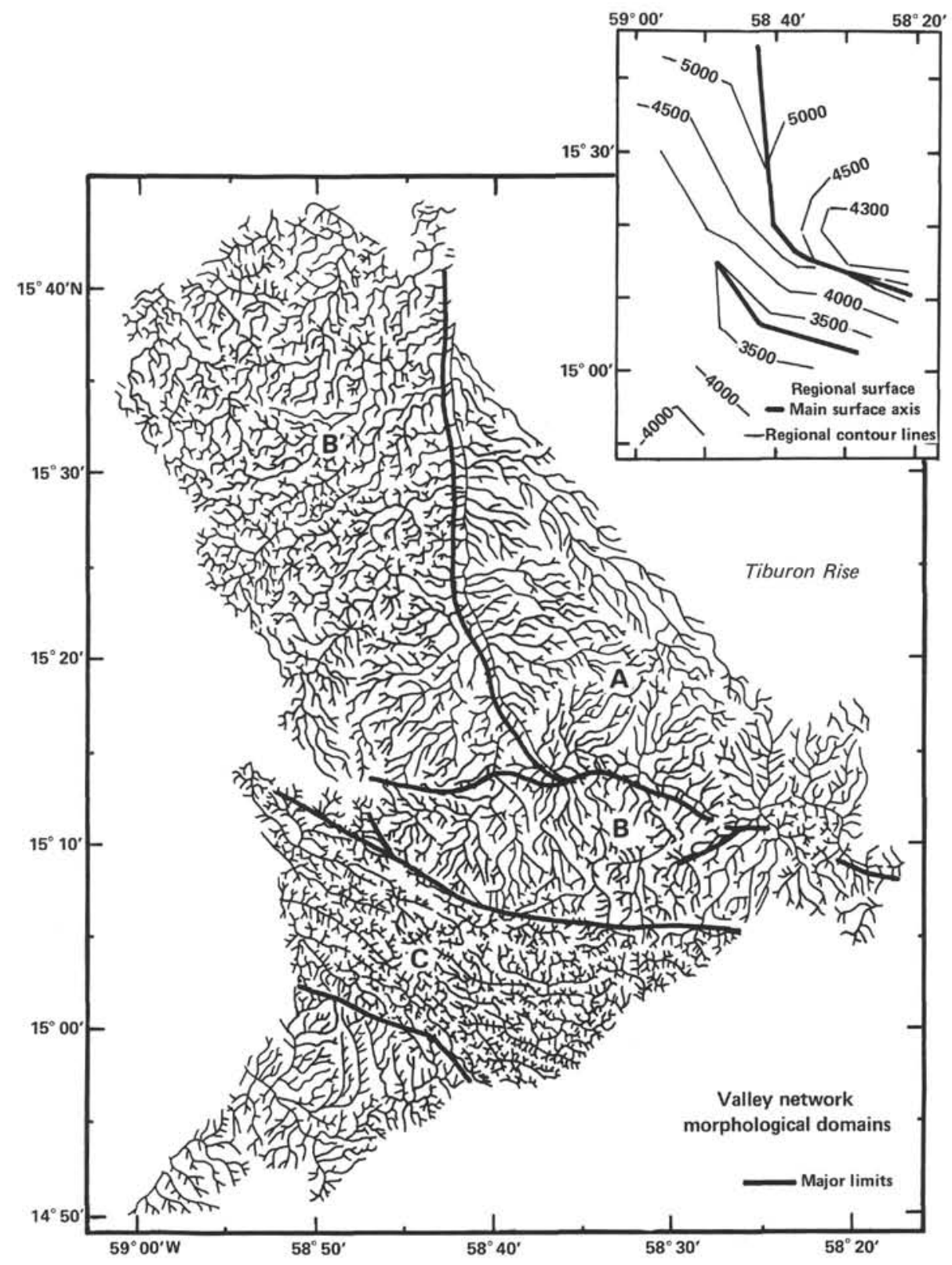

Figure 7. Submarine valley network around the drilling area. In the upper right corner is the regional bathymetric surface inferred from Figure 4 (depths in $\mathrm{m}$ ).

can hypothesize that in those two areas (drilling area and area north of $12^{\circ} 30^{\prime} \mathrm{N}$ ) this discontinuous character of the morphology may be linked to a décollement. The presence of a discontinuity and its depth into the sedimentary section of the underthrusting plate, greatly modify the style of tectonic deformation at the toe of the prism; the size of structures directly depends on the thickness of sediment involved (Fig. 15).

\section{CONCLUSIONS}

Bathymetric mapping by a multibeam tool provides an accurate map of the seafloor topography along the deformation front of the Barbados Ridge. Using the map, several conclusions can be drawn as to structure.
1) The morphology is directly linked to the structure: Figures 6 and 15 show the difference between the southern part of the ridge, where the thick pile of sediments is marked by asymmetric folds and reverse faults, and the drilling area, where the shortening has produced a décollement in the thin sedimentary cover.

2) Combining seismic and Sea Beam data, one can obtain good three-dimensional imagery of the structure (size, amplitude, and length of folds).

3) Since the topography is related to deformation, as is clearly evident in the southern part of Barbados Ridge, the wavelength of the topographic irregularities can give a good idea of the internal structure especially when seismic reflection results are inadequate, as they are in the Leg $78 \mathrm{~A}$ area. 


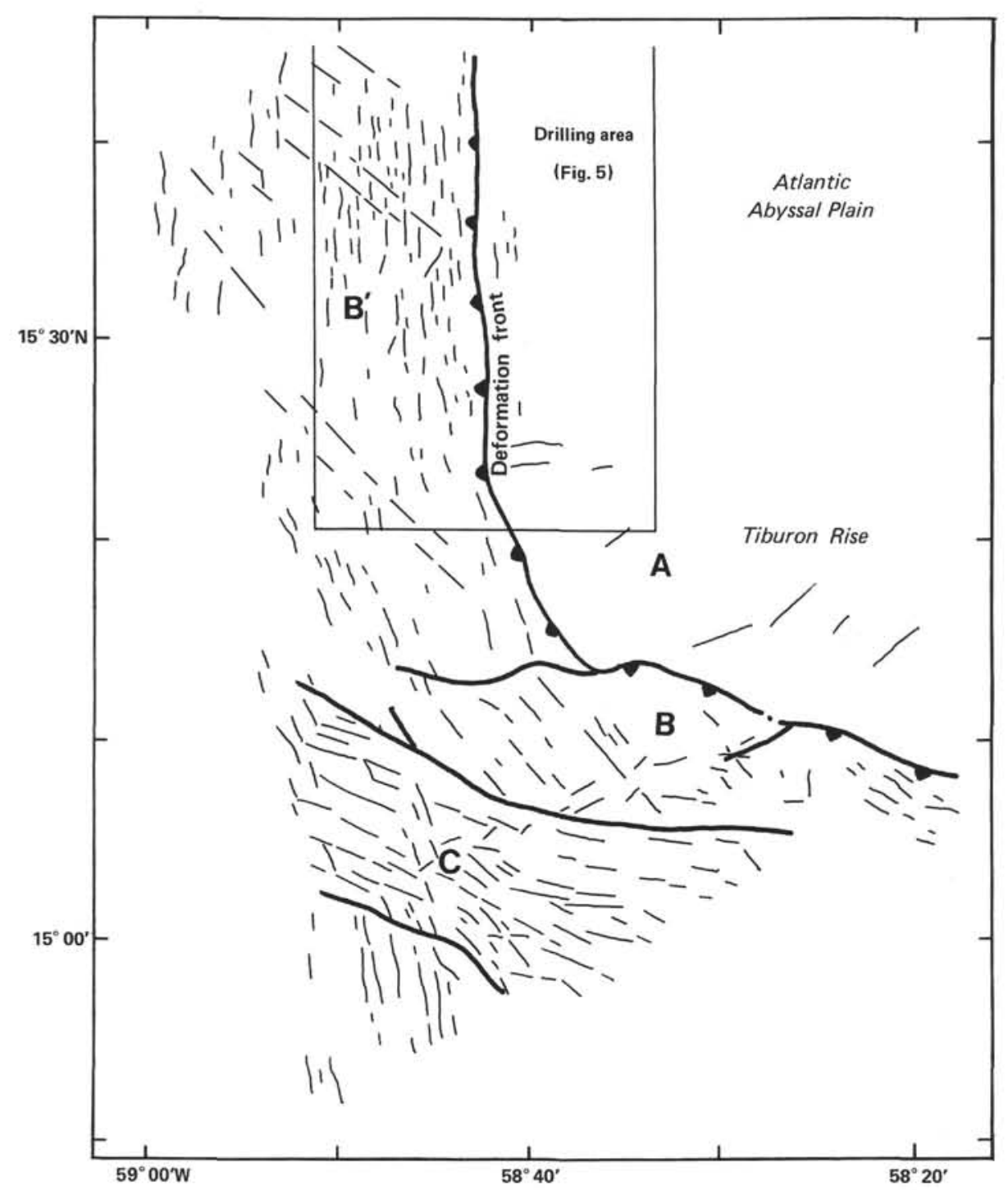

Figure 8. Abnormal lineaments in the valleys around the drilling area.

4) The structure of the underthrusting plate greatly influences the distribution, shape, and size of tectonic features of the deformation front. In particular, south of the drilling area, the Tiburon Rise induces an E-W trend of deformation. Similar but smaller features, oriented $\mathrm{N} 130^{\circ}$, occur in the southern part of the ridge. They may correspond to oblique strike-slip faults.

5) No direct influence of the Tiburon Rise near Sites 541 and 542 is demonstrated. Small and discontinuous asymmetric N-S features are observed. Each eastward slope break is considered to represent the locus of outcropping of reverse faults induced by the shortening (Fig. 16).

6) Uncompacted clays are the source of mud diapirism in the south.

\section{REFERENCES}

Biju-Duval, B., Le Quellec, P., Mascle, A., Renard, V., and Valéry, P., 1982. Multibeam bathymetric survey and high resolution seismic investigations on the Barbados Ridge Complex (Eastern Caribbe- an): a key to the knowledge and interpretation of an accretionary wedge. Tectonophysics, 86:275-304.

Higgins, G. E., and Saunders, J. B., 1974. Mud volcanoes, their nature and origin. In Contribution to the Geology and Paleobiology of the Caribbean and adjacent areas. Verh. Naturforsch. Ges. Basel, 84:101-152.

Mascle, A., Lajat, D., and Nely, G., in press. Sediment deformation linked to subduction and to argilokinesis in the southern Barbados Ridge from multichannel seismic surveys. Trans. Fourth Latin American Geol. Congr., Port of Spain, Trinidad, 1981.

Naudin, J. J., and Prud'homme, R., 1980. L'analyse cartographique: étude numérique des caractéristiques morphologiques des surfaces. 26eme Congr. Internat. Geol., Ser. Inform. Geol., 15:47-71.

Renard, V., and Allenou, J. P., 1979. Sea-Beam, Multibeam echosounding in "Jean Charcot" Description evaluation and first results. Int. Hydrol. Rev., 56:53-67.

Stride, A. H., Belderson, R. H., and Kenyon, N. H., 1982. Structural grain, mud volcanoes and other features on the Barbados Ridge Complex revealed by Gloria long-range side-scan sonar. Mar. Geol., 49:187-196.

Date of Initial Receipt: August 23, 1983

Date of Acceptance: September 21, 1983 


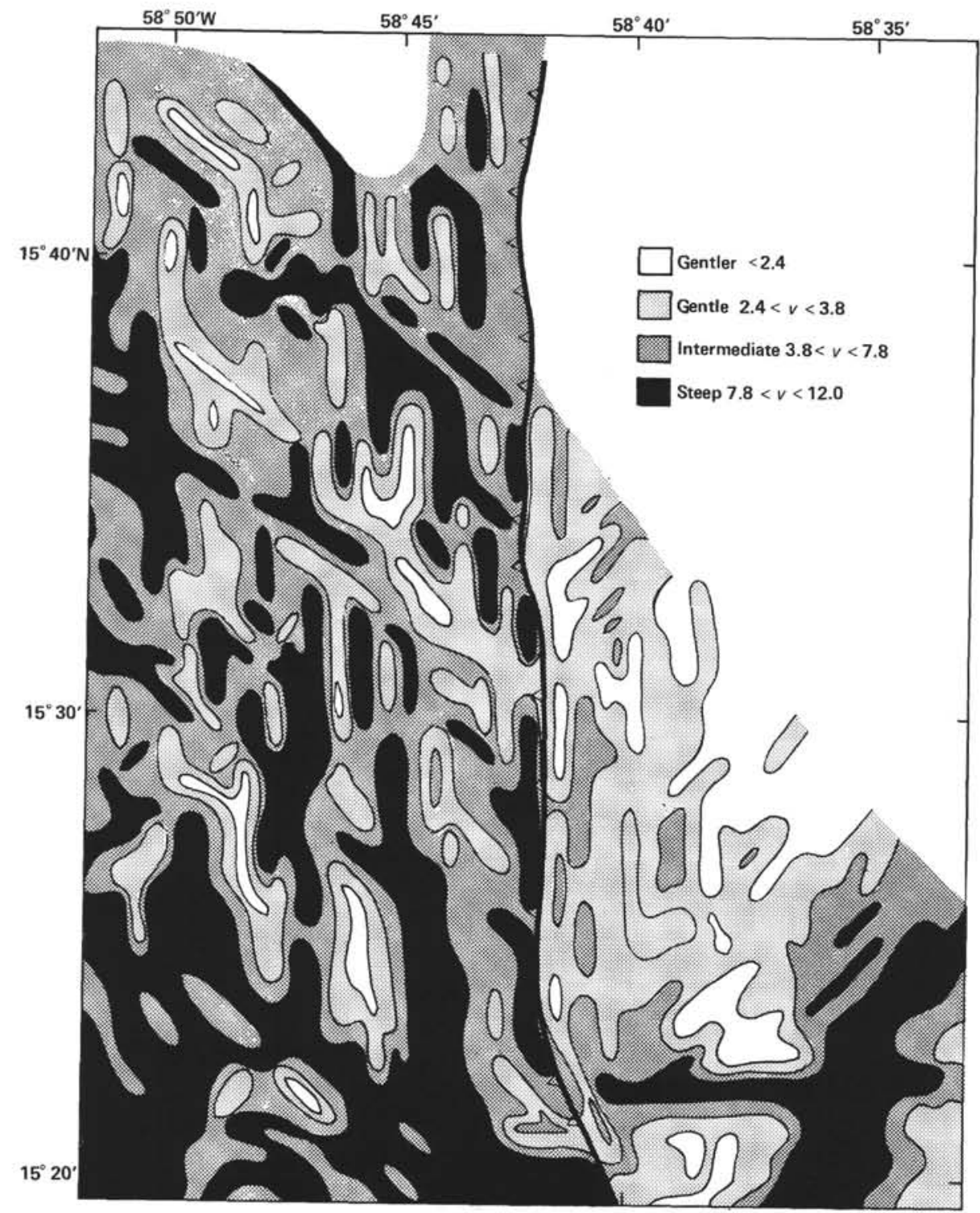

Figure 9. Distribution of values of slope $v(\%)$ in the drilling area. 


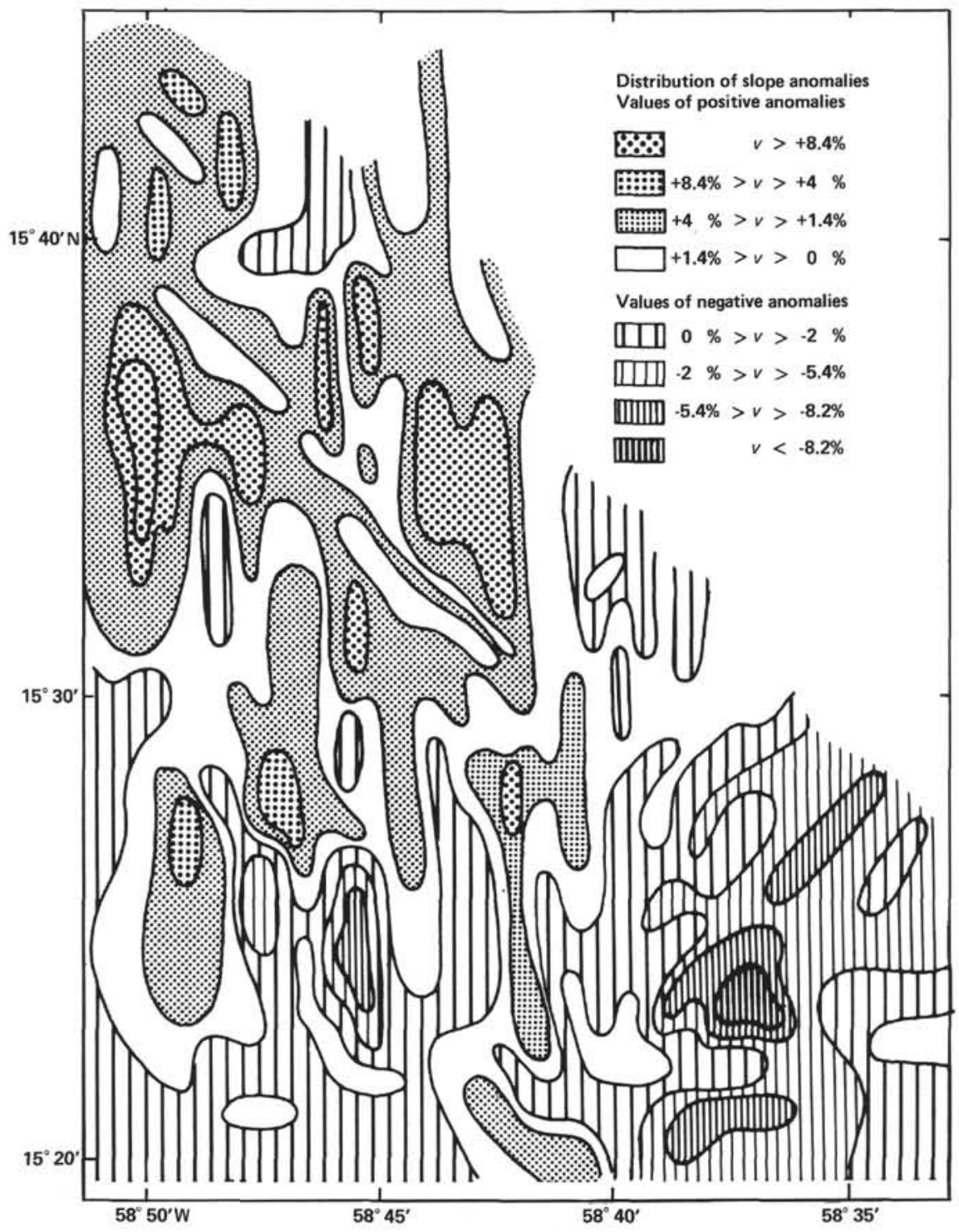

Figure 10. Anomalies of slopes $v(\%)$ in the drilling area. 


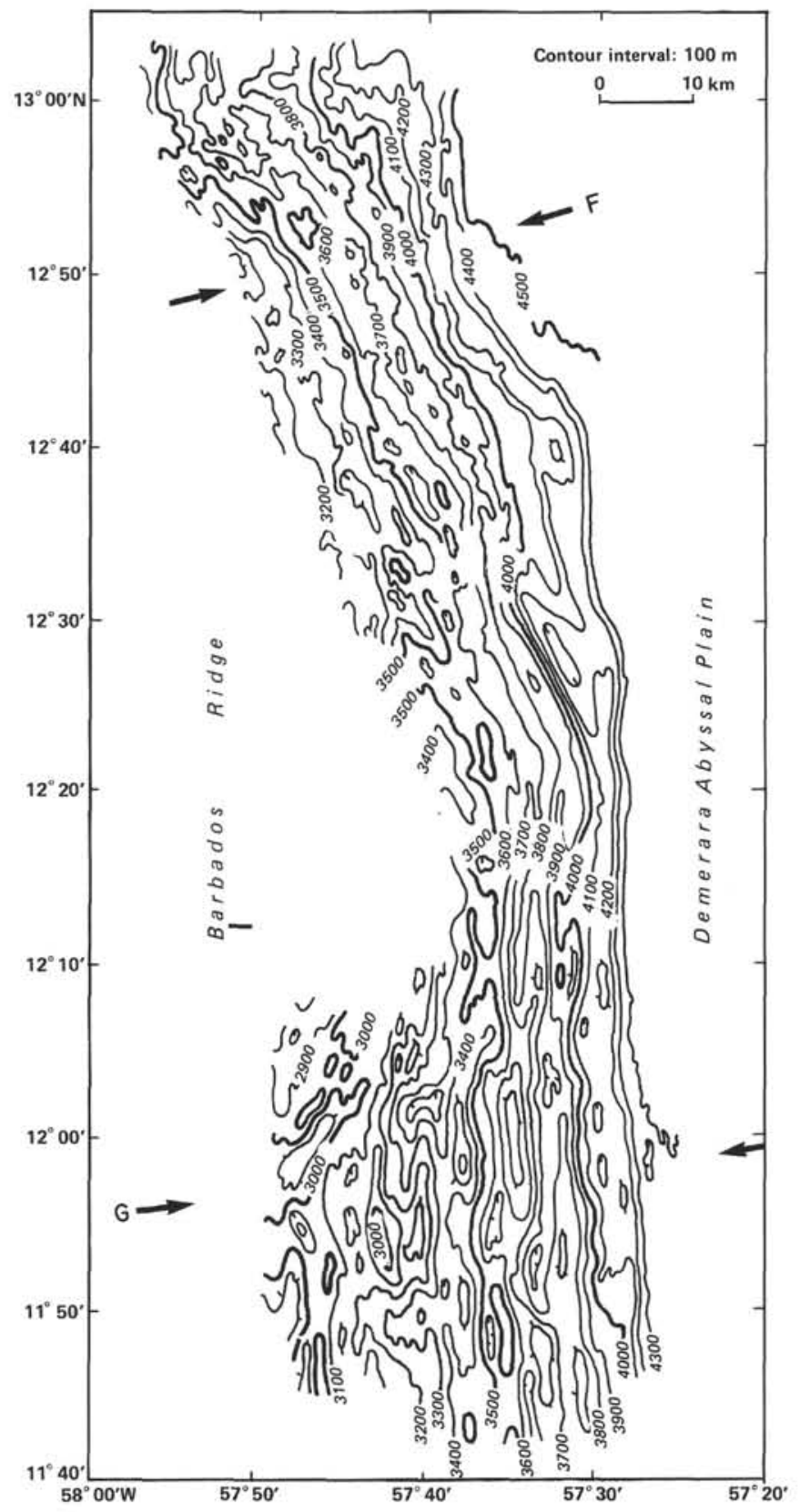

Figure 11. General Sea Beam bathymetric map of the deformation front at the southern part of Barbados Ridge (from Biju-Duval et al., 1982). Arrows indicate locations of profiles from Figure 6. 


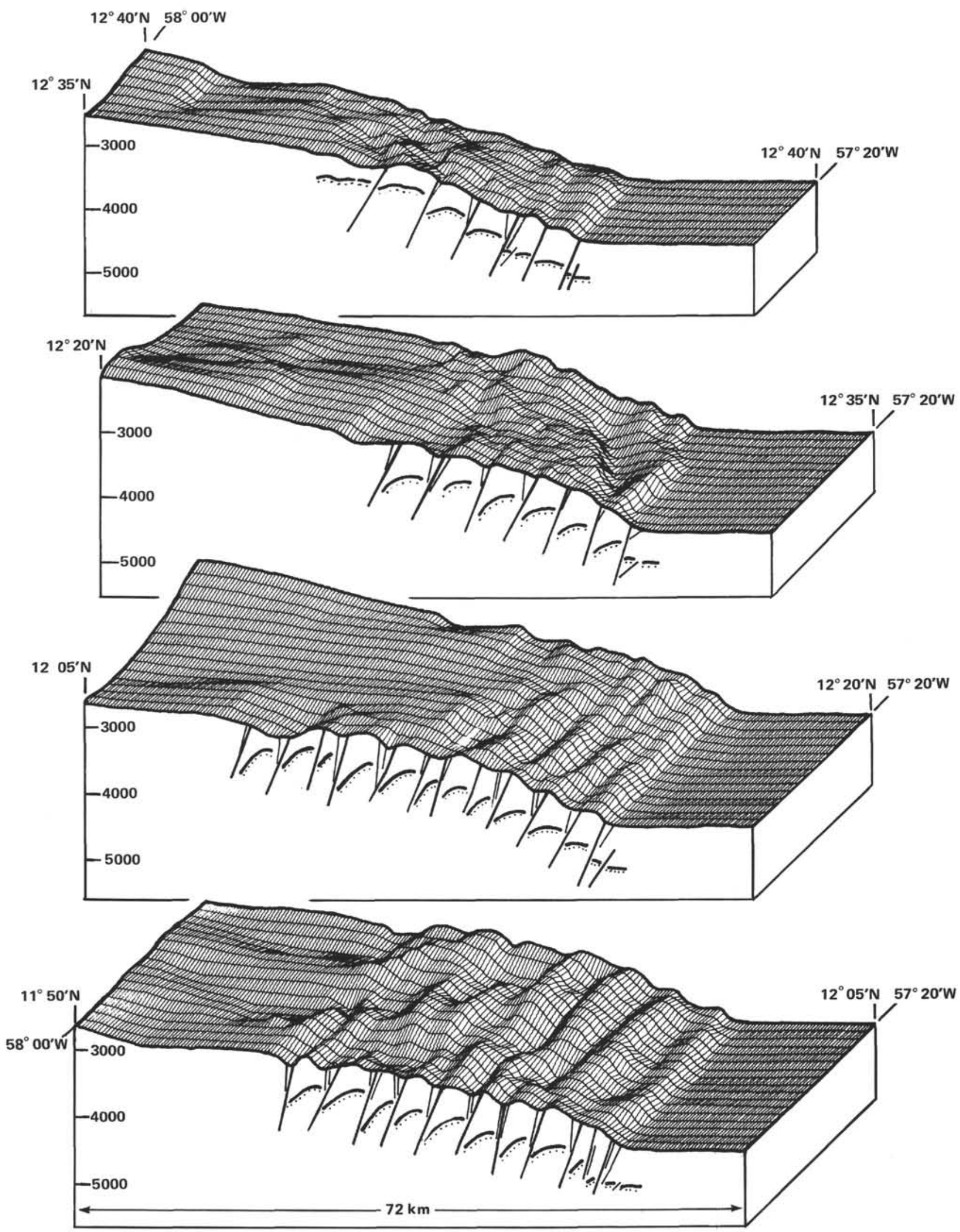

Figure 12. Seafloor-relief block diagram from the Sea Beam bathymetry of the deformation front at the southern part of Barbados Ridge, with interpretative seismic cross-sections (CEPM seismic lines, see Biju-Duval et al., 1982). (Depths in m.) 
P. FONTAS ET AL.

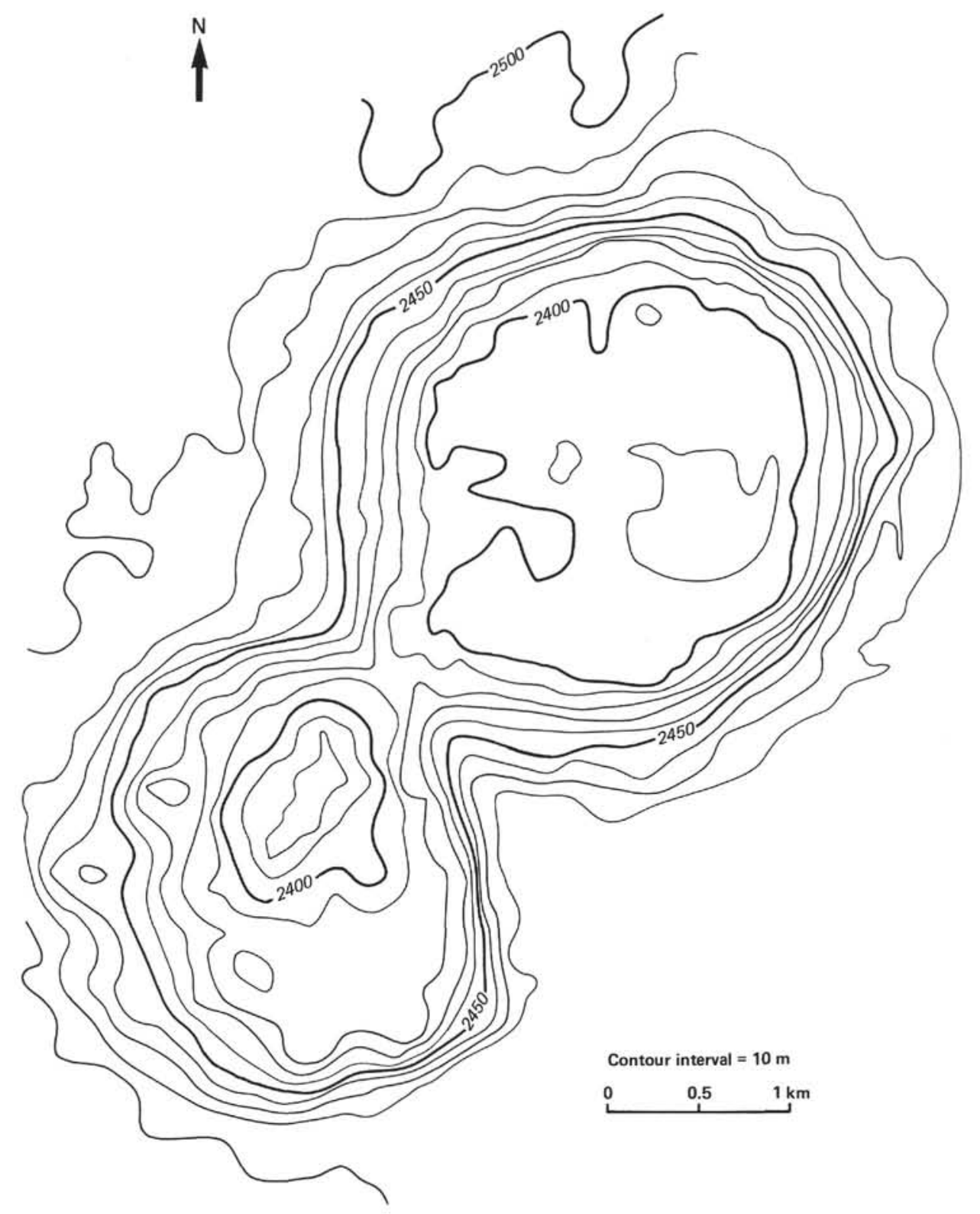

Figure 13. Example of mud diapir structure around $12^{\circ} 03^{\prime} \mathrm{N}, 59^{\circ} 23^{\prime} \mathrm{W}$. 


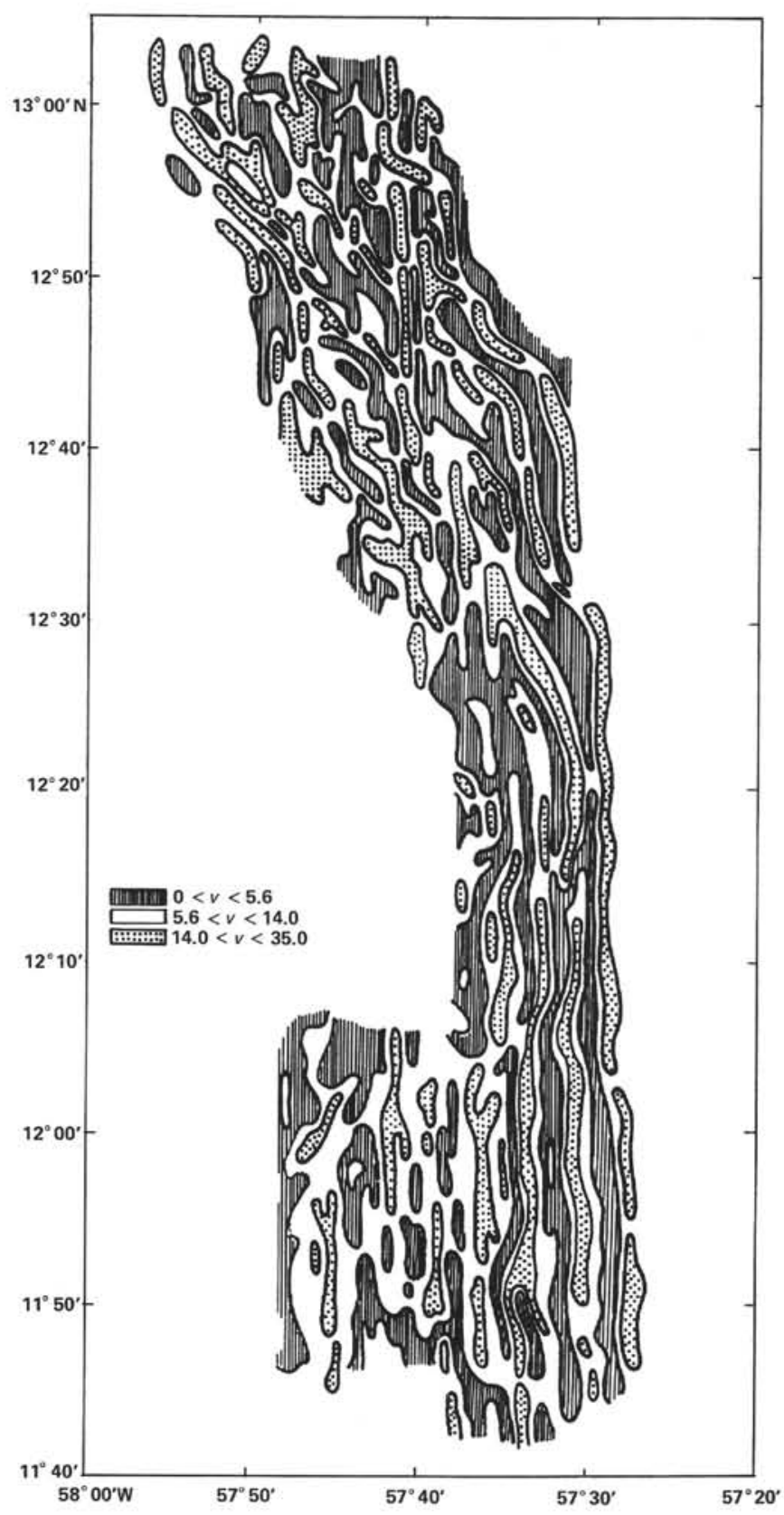

Figure 14. Distribution of values of slope $v(\%)$, southern part of Barbados Ridge. 
A

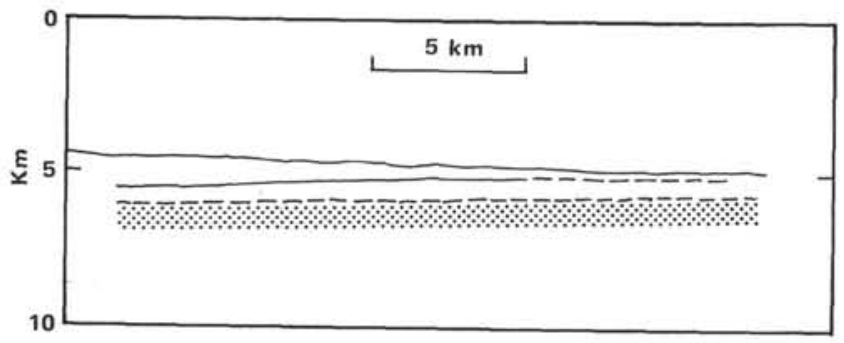

\section{B}

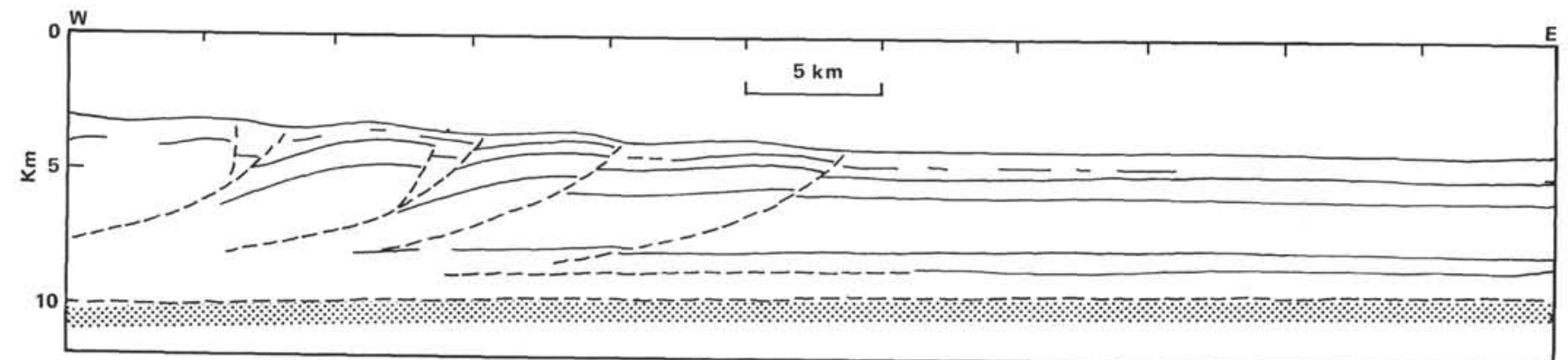

Figure 15. Interpretative cross-sections of the deformation front from CEPM seismic lines. A. In the drilling area (line A1 C, Ngokwey et al., this volume). B. At the southern part of Barbados Ridge (see Biju-Duval et al., 1982).

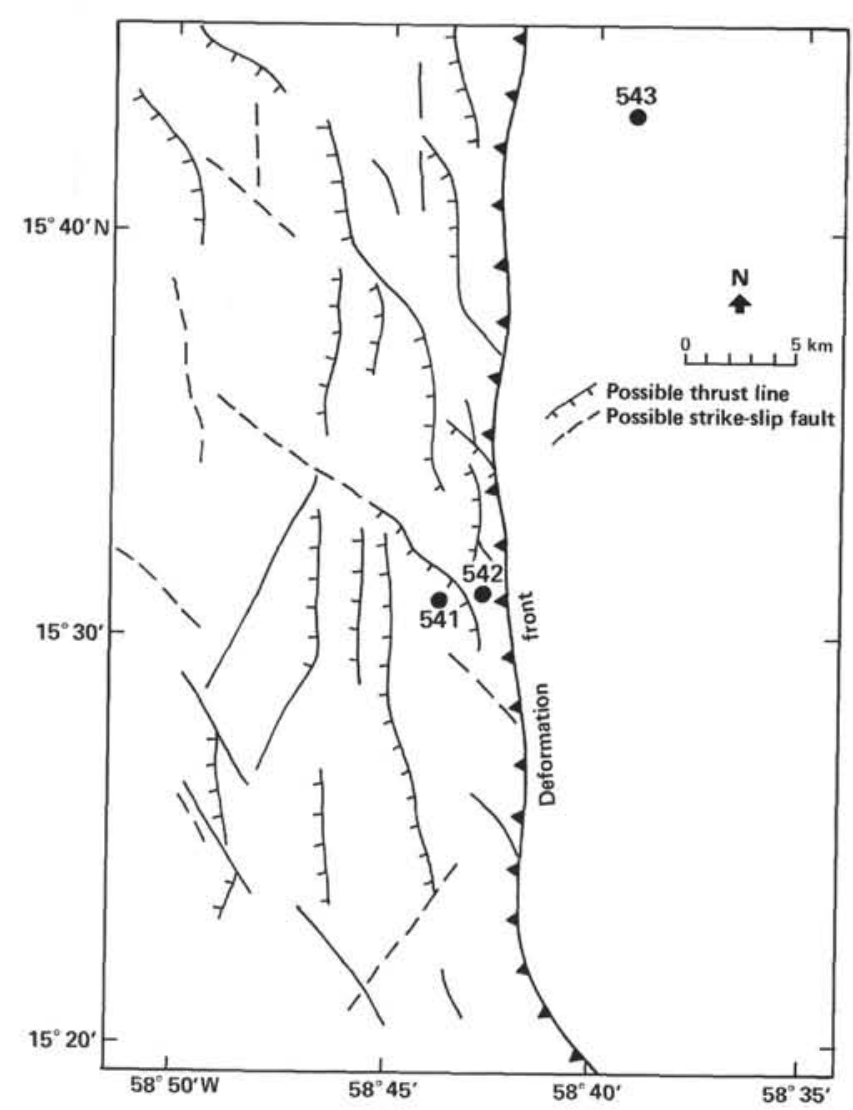

Figure 16. Interpretative structural sketch-map of the drilling area. 